\title{
ECOPHYSIOLOGICAL RESPONSES OF MEDIUM MORPHOTYPE OF Paubrasilia echinata (Lam.)Gagnon,H.C.Lima and G.P.Lewis RAISED UNDER FULL SUNLIGHT AND NATURAL SHADE
}

\author{
Vinícius Novo Gama ${ }^{2}$,Bernardo Pretti Becacici Macieira ${ }^{3 *} \odot$, Leonardo Valandro Zanetti ${ }^{3}$, Dayana Effgen \\ Fantinato $^{3} \odot$, Talita Miranda Teixeira Xavier $^{3}{ }^{\circ}$, José Eduardo Macedo Pezzopane ${ }^{4}$ and Geraldo Rogério \\ Faustini Cuzzuol ${ }^{5}$ (C)
}

\footnotetext{
${ }^{1}$ Received on 13.12.2018 accepted for publication on 22.08.2019.

${ }^{2}$ Universidade Federal do Espírito Santo, Departamento de Ciências Biológicas, Vitória, ES - Brasil . E-mail: <viniciusnovogama@gmail. com> and $<$ bernardopretti@gmail.com $>$.

${ }^{3}$ Universidade Federal do Espírito Santo, Dotourado em Biologia Vegetal, Vitória, ES - Brasil. E-mail: < bernardopretti@gmail.com> $<$ valandroleo@gmail.com>, <defantinato@gmail.com> and <talitamtx@yahoo.com.br>.

${ }^{4}$ Universidade Federal do Espírito Santo, Departamento de Ciências Florestais e da Madeira, Jerônimo Monteiro, ES - Brasil. E-mail: <pezzopane2007@yahoo.com.br>.

${ }^{5}$ Universidade Federal do Espírito Santo, Departamento de Biologia, Vitória, ES - Brasil. E-mail: <gcuzzuol@gmail.com>.

*Corresponding author.
}

\begin{abstract}
The existing inconsistent data on the irradiance needs of Brazilwood plants Paubrasilia echinata (Lam.) Gagnon,H.C.Lima and G.P.Lewis. can be explained by their phenotypical variations. While small-leaf morphotypes grows better in the shade, not tolerating environments with high irradiance, a recently discovered population of medium morphotype presents different behavior: better performance under direct sunlight and limited growth in the shade. In order to understand the physiological mechanisms of the medium morphotype in response to the available irradiance, this study was performed to characterize the oxidative stress metabolism, photochemical and biochemical photosynthesis efficiency, as well as anatomical adjustments of leaves of the medium morphotype of $P$. echinata under different intensities of irradiance. The analyses were performed at direct sunlight condition $\left(2000 \mu \mathrm{mol} \mathrm{m} \mathrm{m}^{-2} \cdot \mathrm{s}^{-1}\right)$ and within a dense ombrophilous forest with $80 \%$ shading $\left(192 \mu \mathrm{mol} \mathrm{m}^{-2} \mathrm{~s}^{-1}\right)$. Growth, leaf anatomy, chloroplast pigments, photochemical (chlorophyll a fluorescence), and biochemical (gaseous exchanges) efficiency, soluble carbohydrates, and antioxidants were measured. The results showed that the higher efficiency in light energy uptake, paired with better photochemical performance and better $\mathrm{CO}_{2}$ fixation in plants under direct sunlight resulted in higher concentration of soluble sugars and growth. The energy that should have been used in photochemical and/or biochemical reactions of shaded plants was dissipated in the form of heat, re-emitted as fluorescence or translocated to the production of antioxidant defense compounds of the secondary metabolism. Therefore, the medium morphotype of $P$. echinata presents an ecological profile of sun-tolerant or pioneer species, and as such, it is recommended its planting in full sunlight. These results differ from previous studies on small morphotype of $P$. echinata and suggest the need for a taxonomic reconstruction of this species, which is essential to adequate management practices in Atlantic rainforest recovery programs.
\end{abstract}

Keywords: Brazilwood; Gas exchange; Oxidation stress.

RESPOSTAS ECOFISIOLÓGICAS DE PLANTAS DO ECOTIPO MÉDIO DE Paubrasilia echinata (LAM.) Gagnon,H.C.Lima e G.P.Lewis CULTIVADAS SOB PLENO SOL E SOMBREAMENTO NATURAL

RESUMO - Os dados existentes e inconsistentes sobre as necessidades de irradiância das plantas de pau-brasil Paubrasilia echinata (Lam.) Gagnon,H.C.Lima e G.P.Lewis. podem ser explicados por suas variações fenotípicas. Enquanto os morfotipos de folhas pequenas apresentam melhor crescimento em sombreamento, não tolerando ambientes com elevada irradiância, uma população de morfotipos médios recentemente descoberta apresenta um 


\begin{abstract}
comportamento diferente: melhor desempenho em intensa luminosidade e crescimento limitado em sombreamento. A fim de compreender os mecanismos fisiológicos do morfotipo médio em termos de disponibilidade de irradiância, este estudo foi realizado para caracterizar o metabolismo do estresse oxidativo, a eficiencia fotoquímica e bioquímica da fotossíntese, bem como os ajustes anatômicos de folhas do morfotipo médio de P. echinata sob

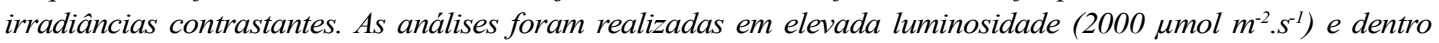

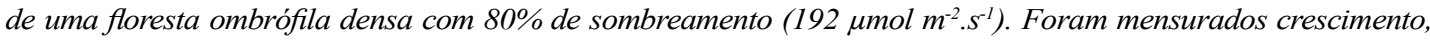
anatomia foliar, pigmentos cloroplastídicos, eficiência fotoquímica (fluorescência da clorofila a) e bioquímica (trocas gasosas), carboidratos solúveis e antioxidantes. Os resultados mostraram que a maior eficiência na captação de energia luminosa, seguido do melhor desempenho fotoquímico e melhor fixação de $\mathrm{CO}_{2}$ nas plantas sob elevada luminosidade, resultaram em maiores concentrações de açúcares solúveis e maior crescimento. A energia que deveria ter sido usada nas reações fotoquímicas elou bioquímicas de plantas sombreadas foi dissipada na forma de calor, reemitida como fluorescência ou translocada para a produção de compostos de defesa antioxidantes do metabolismo secundário. Concluímos que o ecotipo médio de P. echinata apresenta perfil ecológico de espécies tolerante ao sol ou de pioneira sendo recomendado seu plantio em pleno sol. Esses resultados diferem dos estudos anteriormente publicados sobre o ecotipo folha pequena de P. echinata e sugere a necessidade de uma reconstrução taxonômica dessa espécie, o que é fundamental para boas práticas de manejo em programas de recuperação da Floresta Atlântica.
\end{abstract}

Palavras-Chave: Pau-brasil; Trocas gasosas; Estresse oxidativo.

\section{INTRODUCTION}

Recognized worldwide by its mega diversity, the Brazilian Atlantic Forest shelters a number of species that are highly important economically, and culturally, such as Paubrasilia echinata Lam Gagnon,H.C.Lima and G.P.Lewis (Brazilwood) (Gagnon et al., 2016).

Even though the plant is well studied at taxonomic, phytochemical and propagation levels, little is known about Brazilwood's ecophysiology, especially its ecological habit regarding natural light. For Budowski (1965), this is a climax species (ombrophilous), whereas Lima (1992) and Lorenzi (2002) categorize it as heliophilous. For Mengarda et al. (2009), this species has semi-heliophilous or intermediate characteristics, because of its higher growth, photosynthetic capacity, and water-use efficiency of $50 \%$ of photosynthetically active radiation (PAR). Investigating the acclimatization of $P$. echinata plants under contrasting irradiance, Mengarda et al. (2012) found a rapid reduction in the maximum quantum yield of PSII primary photochemical reactions $\left(\varphi \mathrm{P0}=\mathrm{F}_{\mathrm{V}} / \mathrm{F}_{\mathrm{M}}\right)$ and performance index $\left(\mathrm{PI}_{\mathrm{ABS}}\right)$ followed by total leaf abscission during the first week of exposure to direct sunlight. The authors concluded that the species is shade-tolerant or late in forest succession. Thus, these two Mengarda's study showed that $P$. echinata plants are intolerant to the full sunlight.

These conflicting data concerning ecological habits may be related to morphological variations of Brazilwood. Three ecotypes have been reported by Juchum et al.
(2008), in which the most common has smaller leaflets and light orange core and is found on the Brazilian, coast from Rio de Janeiro to Rio Grande do Norte. The second ecotype differs from the first one in that the latter has slightly larger leaflets and orange-reddish core. Natural populations of this ecotype occur in the states of Rio de Janeiro, Espírito Santo, and southern Bahia. The third ecotype does not have subleaflets, only pines made of large leaflets and dark red core, found only in Bahia.

With the recent spread of this information, plants with semi-heliophilous or intermediate habits described by Mengarda et al. (2009) and shade tolerant or late succession (2012) were found to be small ecotypes, according to analyses of pictures in these authors' studies. This leads us to the conclusion that heliophilous (Lima, 1992; Lorenzi, 2002) or ombrophilous (Budowski, 1965) descriptions are related to other ecotypes. Recently, a population of medium ecotype planted in the Brazilian tablelands in the state of Espírito Santo was shown to have strong heliophilous habits (Gama, 2013).

The semi-heliophilous habits of the small ecotype and the heliophilous habit of the medium ecotype suggest deep changes in their primary and secondary metabolism. The small ecotype, which is sensitive to high irradiance, showed marginal leaflet burns, inhibition of gaseous exchanges, deficiency in water use (Mengarda et al., 2009), decrease in chloroplast pigment contents and increase in chlorophyll a fluorescence (Mengarda et al., 2012) under direct sunlight. These photodamage symptoms were followed by an increase in glucose,

Revista Árvore 2019;43(4):e430407 
fructose, sucrose and raffinose contents (Mengarda et al., 2012) associated to antioxidant metabolism (Terashima et al., 2006; Anjum et al., 2017; Portela et al., 2019).

The aim of this study is to characterize medium ecotype antioxidant metabolism and its implications in photosynthesis raised under full sunlight and natural shade exposure to reinforce the need of setting a new ecological structure of $P$. echinata in its possible subspecific taxa. We hypothesize that the medium ecotype of Brazilwood may present a divergent response to the contrast of luminosity compared to other previously reported ecotypes. This echophysiological variation is likely to be hindering a precise classification of this species as well as its reintroduction in natural environments. Such information is essential for handling this species in Atlantic Forest recovery programs.

\section{MATERIALS AND METHODS}

\subsection{Study area and vegetal material}

This study was carried out in a fragment of the Atlantic Forest tableland at the Reserva Natural Vale, located in the municipality of Sooretama, ES, Brazil $\left(19^{\circ} 11^{\prime} 30^{\prime \prime} \mathrm{S}\right.$ and $40^{\circ} 05^{\prime} 46^{\prime \prime} \mathrm{W}$, altitude $\left.58 \mathrm{~m}\right)$. The experiments used non-clonal seeds of medium ecotype of Paubrasilia echinata Lam Gagnon,H.C.Lima and G.P.Lewis. (Leguminosae, Caesalpiniaceae) from the same mother-plant at the same experiment site. Seeding was carried out in a greenhouse using plastic bags with irrigation and controllable environmental conditions $(50 \%$ photosynthetically active radiation intercepted on the site, $80 \%$ relative humidity and $28^{\circ} \mathrm{C}$ ). After two months of germination, seedlings were planted in March 2010 in two areas: under direct sunlight $\left(2000 \mu \mathrm{mol} \mathrm{m} \mathrm{m}^{-2} \cdot \mathrm{s}^{-1}\right)$ and natural shading for

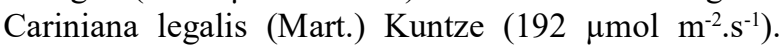
At the beginning of the experiment, the seedlings had a mean height of $20 \mathrm{~cm}$ and 100 sample seedlings for each light condition without fertilization and irrigation as well as ten seedlings were selected for the analyses using the criterion of morphological homogeneity. The area occupied by the experiment comprised 100 square meters. Biometric analyses and leaf collection were performed on February 2012, when the plants were 23 months old. The sampling period was marked by a very dry summer, with precipitation and average temperature of $10.4 \mathrm{~mm}$ and $24^{\circ} \mathrm{C}$, respectively (INMET, 2012). The analyses were carried out from the third to the fourth node of fully expanded leaves. The leaf samples were collected, frozen in liquid nitrogen for transport and stored in ultrafreezer $\left(-80^{\circ} \mathrm{C}\right)$.

\subsection{Growth analyses}

For growth analyses, the height and diameter of the stem of ten (10) plants in each irradiance environment were measured. Leaf area was measured using Area Meter, LI-COR 3100, Nebraska, USA. From these data, we calculated specific leaf mass $(\mathrm{SLM}=\mathrm{LFM} / \mathrm{LA})$ as per Hunt (1982), and water content or succulence (Teor $\mathrm{H}_{2} \mathrm{O}=$ LFM-LDM/LA), according to Parida et al. (2004), where LFM = leaflet fresh mass, LA = leaflet area, and LDM = leaflet dry mass.

\subsection{Leaf anatomy}

Fourth node leaves of six (6) plants in each irradiance environment were collected and fixed in FAA 70 (formaldehyde, acetic acid, and ethanol 70\%) for 48 hours and stored in alcohol $70 \%(\mathrm{v} / \mathrm{v})$. Samples of the limb middle third in the internervural regions and midrib leaf areas were sliced by hand using table microtome with steel blades. The slices were colored with safrablau and the histological blades were mounted with glycerin gelatin (Bukatsch, 1972). For stomatal quantification, abaxial leaf epidermis was printed on glass blade using cyanoacrylate ester (Super Bonder ${ }^{\circledR}$, USA).

\subsection{Photosynthetic pigments}

Chlorophyll $a$ (Chl. $a)$, Chlorophyll $b$ (Chl. b), total chlorophyll and carotenoid (Carot.) contents and Chlorophyll $a / b(\mathrm{Chl} . a / b)$ and Chlorophyll/Carotenoid (Chl./Carot.) ratios were determined using 4 leaf discs of $0.45 \mathrm{~cm}$ in diameter each of six (6) plants in each irradiance environment. The discs were stored in amber tubes with $7 \mathrm{~mL}$ of dimethyl sulfoxide (DMSO) and incubated in a water bath at $65^{\circ} \mathrm{C}$ for 24 hours (Hiscox and Israelstam, 1979). The readings were carried out in spectrophotometer (Genesys 10S UV-Vis, Thermo Fisher Scientific, Waltham, USA) at the wavelengths of 470, 645 and $663 \mathrm{~nm}$, and pigment concentration was determined using Arnon (1949) and Lichtenthaler (1987) equations.

\subsection{Kinetics of transient or polyphase fluorescence emission (OJIP)}

Fluorescence emission kinetics was measured between 8:00 am and 9:30 am, in the same subleaflet collected to extract pigments, after acclimatization in the dark for 30 minutes using leaf clips (Strasser 
et al., 2004). Then, a saturating light beam of 3,000 $\mu \mathrm{mol} \mathrm{m} \mathrm{m}^{-2} \cdot \mathrm{s}^{-1}$ was induced in a $4 \mathrm{~mm}$ diameter area of the subleaflet. OJIP Fluorescence transient $(10 \mu \mathrm{s}$ at 1 s) was measured using fluorimeter Handy-PEA (Plant Efficiency Analyzer, Hansatech Instruments Ltd, King's Lynn Norfolk, UK). The results were tabulated using the application software Biolyzer (Laboratory of Bioenergetics, University of Geneva, Switzerland) for an electronic spreadsheet (Strasser et al., 2004).

The OJIP fluorescence transient curves were normalized based on the relative variable between points $\mathrm{O}$ and $\mathrm{P}\left[\mathrm{V}_{\mathrm{t}}=\left(\mathrm{F}_{\mathrm{t}}-\mathrm{F}_{0}\right) /\left(\mathrm{F}_{\mathrm{M}}-\mathrm{F}_{0}\right)\right]$. The definitions and equations of the OJIP test adopted followed Strasser et al. (2004), from which the following parameters were chosen: RC/ABS Index, which represents the quantity of active reaction centers (RCs) per energy absorbed; quantum yield of photochemical reactions during absorption until reduction of primary electron acceptor of photosystem II - PSII $\left(\mathrm{Q}_{\mathrm{A}^{-}}\right)\left(\mathrm{TR}_{0} / \mathrm{ABS}=\mathrm{F}_{\mathrm{V}} / \mathrm{F}_{\mathrm{M}}\right)$; quantum yield in electron transport from QA- to pool of plastoquinone $(\mathrm{PQ})\left(\mathrm{ET}_{0} / \mathrm{ABS}=1-\mathrm{F}_{\mathrm{J}} / \mathrm{F}_{\mathrm{M}}\right)$; quantum yield in the reduction of final acceptors of photosystem $\mathrm{I}$ - PSI $\left(\mathrm{RE}_{0} / \mathrm{ABS}=1-\mathrm{F}_{\mathrm{I}} / \mathrm{F}_{\mathrm{M}}\right)$; efficiency of electron movement through electron transport chain transporters from $\mathrm{Q}_{\mathrm{A}}$ - to PQ $\left(\mathrm{ET}_{0} / \mathrm{TR}_{0}\right)$ and reduced PQ for PSI final acceptors $\left(\mathrm{RE}_{0} / \mathrm{ET}_{0}\right)$; photosynthetic performance indices from excitation to reduction of intersystem electron acceptors $\left(\mathrm{PI}_{\mathrm{ABS}}\right)$ and from excitation to reduction of PSI final acceptors ( $\left.\mathrm{PI}_{\mathrm{TOTAL}}\right)$; and specific flow of energy dissipation at antenna chlorophyll level, $\mathrm{DI}_{0} / \mathrm{RC}$. We use twenty (20) plants per treatment.

\subsection{Gaseous exchanges}

Analyses of gas exchange were carried out along with fluorescence analyses, in a closed system using a portable infrared gas analyzer (IRGA) model LCi (ADC BioScientific LCi Analyzer), under atmospheric concentration (400 $\left.\mathrm{CO}_{2} \mathrm{ppm}\right)$ and natural lighting: direct sunlight of $1,000 \mu \mathrm{mol} \mathrm{m} \mathrm{m}^{-2} \cdot \mathrm{s}^{-1}$ irradiance and natural shading of $192 \mu \mathrm{mol} \mathrm{m} \mathrm{m}^{-2} \cdot \mathrm{s}^{-1}$. We evaluated carbon photosynthetic assimilation $(A)$, stomatal conductance $\left(g_{s}\right)$, transpiration $(E)$ and leaf inner carbon $\left(C_{i}\right)$ of ten plants per treatment at the same time fluorescence emission kinetics was measured (between 8:00 am and 9:30 am). We also calculated water-use efficiency (WUE) by equation $A / E$, intrinsic water-use efficiency (iWUE) by equation $A / g_{s}$ and instantaneous carboxylation efficiency $\left(\mathrm{P}_{\mathrm{n}} / \mathrm{C}_{\mathrm{i}}\right)$ by equation $A / C_{i}$. We used twenty (20) plants per treatment.

\subsection{Extraction and quantification of soluble carbohydrates}

From the same leaf which chloroplast pigments were extracted, we removed $1.0 \mathrm{~g}$ of the fresh mass of the central internervural region of six (6) plants. The samples were boiled in $10 \mathrm{~mL}$ ethanol $80 \%$ for 3 minutes for enzymatic inactivation. They were then macerated and submitted to soluble carbohydrate extraction in a water bath at $80^{\circ} \mathrm{C}$ for 15 minutes. The extract was centrifuged for 15 minutes at room temperature of $25^{\circ} \mathrm{C}$, the supernatant was removed and operation repeated twice more. Supernatants were put together, homogenized and concentrated in a rotary evaporator (Quimis ${ }^{\circledR}, \mathrm{Q} 344 \mathrm{~B} 1$, Diadema, Brazil) at $40^{\circ} \mathrm{C}$. The carbohydrates were resuspended in $10 \mathrm{~mL}$ of deionized water, and the final extract was stored in a freezer at $-20^{\circ} \mathrm{C}$ for later analysis.

Total concentration of soluble sugars was determined by the phenol sulfuric acid method (Dubois et al., 1956); of free and combined fructose, by acid hydrolysis of anthrone $0.2 \%$ in sulfuric acid (Jermyn, 1956); and of sucrose, by degradation of reducing carbohydrates by potassium hydroxide (KOH $5.4 \mathrm{~N}$ ) as described by Riazi et al. (1985). Fructose rates from 0 to $50 \mu \mathrm{g}$ were used for the standard curve and absorbance readings conducted using spectrophotometer (Genesys 10S UV-Vis, Thermo Fisher Scientific, Waltham, USA) at $620 \mathrm{~nm}$.

Glucose in its free form was estimated with the use of the enzymatic method and a BioSystem kit. The reaction consists in the action of glucose oxidase and peroxidase over reagents glucose and aminoantipirin+phenol, respectively, which release quinone-imine using standard solution of $10 \mu \mathrm{g}$ glucose/urea/creatinine. Absorbancy readings were carried out at $500 \mathrm{~nm}$.

\subsection{Determination of antioxidant activity}

From the same leaves used for analyzing pigments and carbohydrates (six plants in each irradiance environment), $0.4 \mathrm{~g}$ of fresh mass were macerated with polyvinylpolypyrrolidone (PVPP) $1 \%(\mathrm{p} / \mathrm{v})$ in order to obtain the enzymatic extract of superoxide dismutase (SOD, E.C. 1.15.1.1). The solution was homogenized in $2 \mathrm{~mL}$ phosphate buffer (50 mM, pH 7.5), EDTA-Na 1 $\mathrm{mM}, \mathrm{NaCl} 50 \mathrm{mM}$, and ascorbic acid $1 \mathrm{mN}$. The extract was centrifuged for 25 minutes at $2^{\circ} \mathrm{C}$ (Bulbovas et al., 2005). The supernatant was separated in plastic threaded tubes for later analyses.

Revista Árvore 2019;43(4):e430407 
For dosing the activity of superoxide dismutase, a cocktail of the enzyme reaction medium was prepared. Methionine and riboflavin were prepared in the dark and kept in containers wrapped in aluminum foil to avoid photo-oxidation. Nitro blue tetrazolium (NBT) was the last reagent to be prepared, that is, only at the time of reaction. It was made with the same care as before to avoid photo-oxidation. The cocktail was made up of $0.5 \mathrm{~mL}$ of EDTA- $\mathrm{Na}_{2} 0.54 \mathrm{mM}, 0.8 \mathrm{~mL}$ of potassium phosphate buffer (0.1 M, pH 7.0), $0.5 \mathrm{~mL}$ of methionine $0.13 \mathrm{mM}, 0.5 \mathrm{~mL}$ of p-Nitro blue tetrazolium (NBT) $0.44 \mathrm{mM}$ and $0.2 \mathrm{~mL}$ of riboflavin $1 \mathrm{mM}$, and the resulting solution was exposed to fluorescent light (80 W) for 20 minutes. Extracts prepared following the same procedure were kept in the dark. Absorbancy of the solution was measured in a spectrophotometer (Genesys 10S UV-Vis, Thermo Fisher Scientific, Waltham, USA) at $560 \mathrm{~nm}$ (Bulbovas et al., 2005).

Guaiacol peroxidase activity (POD. EC. 1.11.1.7) was determined with $0.3 \mathrm{~g}$ of fresh leaf mass homogenized with phosphate buffer $(0.1 \mathrm{M}, \mathrm{pH} 7.0)$ and polyvinylpolypyrrolidone (PVPP) 2\%. Right after that, the extract was centrifuged for 30 minutes at $2^{\circ} \mathrm{C}$. After adding $2 \mathrm{~mL}$ of phosphate buffer $(0.1 \mathrm{M}, \mathrm{pH} 5.5)$, $0.3 \mathrm{~mL}$ of guaiacol $(1 \%)$ and $0.05 \mathrm{~mL}$ of hydrogen peroxide $(0.3 \%)$ to the supernatant, as per Klumpp et al. (1989), we carried out an absorbancy reading in a spectrophotometer (Genesys 10S UV-Vis, Thermo Fisher Scientific, Waltham, USA) at $485 \mathrm{~nm}$. The absorbancy of the complex $\mathrm{H}_{2} \mathrm{O}_{2}-\mathrm{POD}$ formed was measured at two stages within a linear range of the reaction curve. Delta of absorbency $(\Delta \mathrm{E})$ was divided by the time in which both measurements were registered (at 2.0 and 3.5 minutes), which shows the POD activity during the reduction of hydrogen peroxide (Bulbovas et al., 2005).

Determination of phenolic compounds was carried out using the same alcoholic extract from carbohydrate analyses, and the calibration equation was obtained from the gallic acid standard curve. During the absorbency reading stage, $0.02 \mathrm{~mL}$ of an alcoholic extract solution were mixed to $0.2 \mathrm{~mL}$ of Folin-Ciocalteu. After 5 minutes of reaction, $3.23 \mathrm{~mL}$ of distilled water and 50 $\mu \mathrm{L}$ of sodium carbonate were added to the contents in the vortex. Next, the mixture was allowed to rest for two hours at room temperature (Hossain and Rahman, 2011). The readings were performed at $760 \mathrm{~nm}$ using a spectrophotometer (Genesys 10S UV-Vis, Thermo Fisher Scientific, Waltham, USA).
Determination of total anti-oxidant capacity (ABTS method) was carried out using the same alcoholic extract of the carbohydrate analyses. This analysis was adapted based on the method proposed by Lako et al. (2007). Cationic radical ABTS •+ was produced from the reaction of $7 \mathrm{mM} \mathrm{2.20-azino-bis}$ (3-ethylbenzothiazoline-6-sulfonic acid) diammonium salt (ABTS) and $2.45 \mathrm{mM}$ of potassium persulfate. It was subsequently diluted with distilled water and the content transferred to an amber flask was allowed to rest at room temperature for 24 hours. The readings were performed with $10 \mathrm{~mL}$ of the ABTS solution and $5 \mu \mathrm{L}$ of alcoholic sample at $734 \mathrm{~nm}$ using a spectrophotometer (Genesys 10S UV-Vis, Thermo Fisher Scientific, Waltham, USA). In order to calculate total anti-oxidant capacity, we carried out a standard curve calibration of Trolox equivalents (6-hydroxy2,5,7,8-tetramethylchroman-2-carboxylic acid).

\subsection{Statistical analysis}

The experimental design was completely randomized (CRD) for each treatment. The results were subjected to analysis of variance (ANOVA) at a 5\% level of significance $(P<0.05)$. All analyses were carried out using Assistat, version 7.6 beta (Federal University of Campina Grande, Campina Grande, PB, Brazil).

\section{RESULTS}

\subsection{Morphology and leaf anatomy}

P. echinata plants under direct sunlight had growth values significantly higher compared to those under natural shading (Table 1). Under direct sunlight, average height was $140 \mathrm{~cm}$ and stem diameter $26 \mathrm{~cm}$, whereas plants in the natural shading population had growth $1 / 3$ lower: $45 \mathrm{~cm}$ high and $8 \mathrm{~cm}$ of stem diameter. Specific leaf mass (SLM) and leaf water content were also higher among the population grown under direct sunlight. The radiation difference did not interfere in the unit leaf area (ULA) in both treatments.

For anatomic variables, we verified higher tissue thickness among plants in full sunlight, based on cellular growth, not increase in cellular layers (Table 1). Parenchyma tissues, cuticle and epidermis were thicker under direct sunlight, which was reflected by increased leaf limb thickness. Also, stomatal density was higher in the same treatment.

\section{Revista Árvore 2019;43(4):e430407}


Table 1 - Variable measurements of leaves from medium ecotype plants of Paubrasilia echinata Lam Gagnon,H.C.Lima and G.P.Lewis. grown in full sunlight and natural shade. ULA = unit leaf area; SLM = specific leaf mass; Chl. $=$ chlorophyll; Carot. $=$ carotenoids; $\mathrm{DM}=$ dry mass.

Tabela 1 - Medições das variáveis de folhas de plantas do morfotipo médio de Paubrasilia echinata Lam Gagnon,H.C.Lima e G.P.Lewis. cultivado em pleno sol e sombreamento natural. ULA = área foliar unitária; $S L M=$ massa foliar especifica; Chl. = clorofila $;$ Carot.$=$ carotenoides; $D M=$ massa seca.

\begin{tabular}{|c|c|c|c|}
\hline \multirow[t]{2}{*}{ Variables } & \multirow[t]{2}{*}{ Category } & \multicolumn{2}{|c|}{ Treatment } \\
\hline & & Full sunlight & Natural shade \\
\hline Height (cm) & Growth rate & $140^{*}$ & 45 \\
\hline Stem diameter $(\mathrm{cm})$ & & $26^{*}$ & 8 \\
\hline Water content $\left(\mathrm{mg} \mathrm{H}_{2} \mathrm{O} \mathrm{cm}{ }^{-2}\right)$ & & $0.2^{*}$ & 0.1 \\
\hline $\operatorname{ULA}\left(\mathrm{cm}^{2} \cdot \mathrm{g}^{-1} \mathrm{FM}\right)$ & & 8.2 & 7.7 \\
\hline SLM (mg. FM cm²) & & $0.03 *$ & 0.02 \\
\hline$\overline{\text { Leaf }(\mu \mathrm{m})}$ & Anatomy & $389 *$ & 315 \\
\hline Cuticle $(\mu \mathrm{m})$ & & $10 *$ & 5 \\
\hline Adaxial epidermis $(\mu \mathrm{m})$ & & $21 *$ & 16 \\
\hline Abaxial epidermis $(\mu \mathrm{m})$ & & $17 *$ & 14 \\
\hline Palisade parenchyma - PP $(\mu \mathrm{m})$ & & $93 *$ & 67 \\
\hline Spongy parenchyma - SP $(\mu \mathrm{m})$ & & $234^{*}$ & 200 \\
\hline $\mathrm{SP} / \mathrm{PP}(\mu \mathrm{m})$ & & $2.5^{*}$ & 3.2 \\
\hline Stomatal density $\left(\mathrm{mm}^{2}\right)$ & & $239 *$ & 153 \\
\hline Chl. $a\left(\mathrm{mg} . \mathrm{g}^{-1} \mathrm{DM}\right)$ & Photosynthetic pigments & $1.61 *$ & 3.20 \\
\hline Chl. $b$ (mg.g $\left.\mathrm{g}^{-1} \mathrm{DM}\right)$ & & $1.11 *$ & 3.19 \\
\hline Chl.Total (mg.g $\left.{ }^{-1} \mathrm{DM}\right)$ & & $2.96^{*}$ & 5.71 \\
\hline Carot. (mg.g-1 DM) & & $1.23 *$ & 2.55 \\
\hline Chl. $a / b\left(\mathrm{mg} \cdot \mathrm{g}^{-1} \mathrm{DM}\right)$ & & 1.81 & 1.18 \\
\hline Chl./Carot. (mg.g ${ }^{-1}$ DM) & & 2.87 & 2.53 \\
\hline$\overline{\left.\text { Glucose (mg.g } \mathrm{g}^{-1} \mathrm{DM}\right)}$ & Soluble carbohydrates & $7.8^{*}$ & 3.8 \\
\hline Fructose (mg.g-1 DM) & & $18.9 *$ & 17.2 \\
\hline Sucrose (mg.g ${ }^{-1}$ DM) & & 23.6 & 23.1 \\
\hline Total sugars (mg.g $\left.{ }^{-1} \mathrm{DM}\right)$ & & $25.6^{*}$ & 24.0 \\
\hline
\end{tabular}

\subsection{Chloroplast pigments}

Irradiance intensity influenced pigment content (Table 1). Under natural shading, pigment concentrations Chl. $a$, Chl. $b, \mathrm{Chl}_{\text {Total }}$ and Carot. were $50 \%$ higher compared to plants in full sunlight. These pigment differences between treatments did not influence significantly the ratios Chl. $a / b$ and Chl./Carot.

\subsection{Kinetics of transient or polyphase fluorescence emission (OJIP)}

The plants in natural shading showed higher levels of fluorescence in phases O-J-I (Figure 1A).
These high levels of energy dissipation were reflected by the low values of parameters shown in Figure 1B for plants in natural shading. The density of active reaction centers of PSII (RC/ABS), the energy capture yields $\left(\mathrm{TR}_{0} / \mathrm{ABS}\right)$ and the probability of $\mathrm{a} \mathrm{Q}_{\mathrm{A}}$ electron entering the transport chain $\left(\mathrm{ET}_{0} / \mathrm{TR}_{0}\right)$ were lower among plants in natural shading. However, the index that shows the efficiency of reduced plastoquinone electron movement to final PSI acceptors $\left(\mathrm{RE}_{0} / \mathrm{ET}_{0}\right)$ was higher among shaded plants. This result can be confirmed at the (I-P) stage of these plants, the only stage that did not show discrepant levels compared to directly sunlit plants (Figure 1A). 
(A)

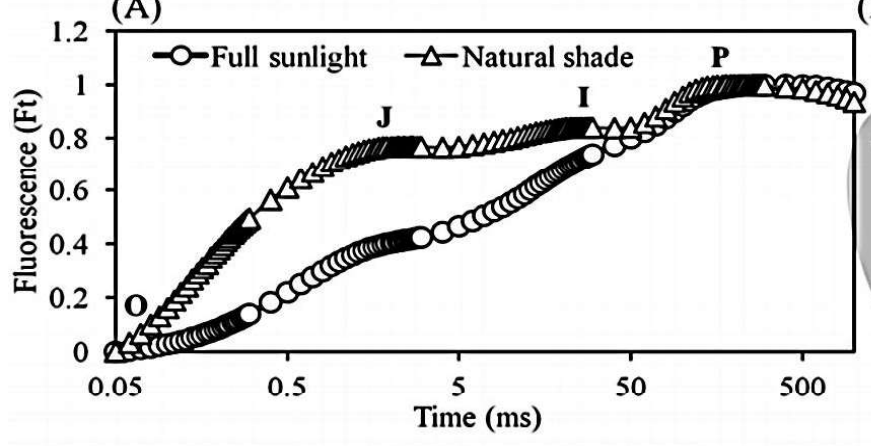

(B)

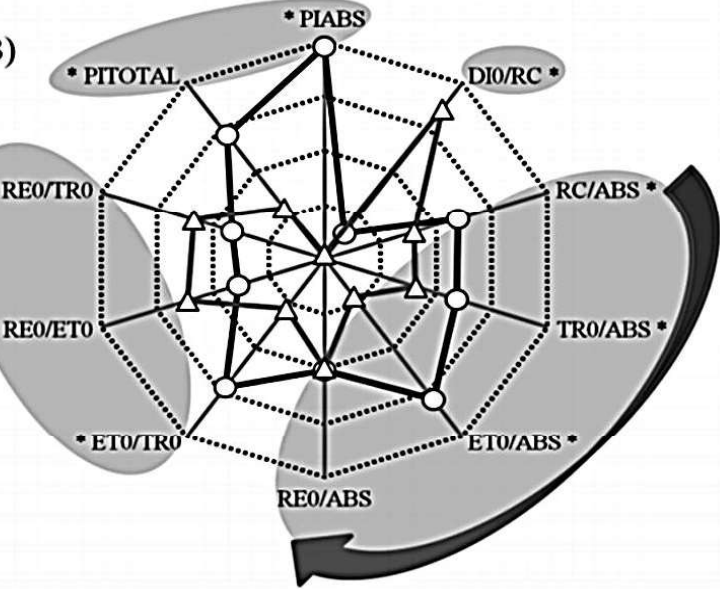

Figure 1 - Chorophyll a fluorescence of medium ecotype plants of Paubrasilia echinata Lam Gagnon,H.C.Lima and G.P.Lewis. under contrasting irradiance. (A) Kinetics of chlorophyll a fluorescence (OJIP curve) and (B) mathematical parameters deduced from the curve OJIP of leaves of the medium ecotype of P. echinata Lam. grown in full sunlight $(\mathrm{O})$ and natural shade $(\Delta)$. DI $\mathrm{RC}$ is the specific flow of energy dissipation at antenna chlorophyll level; $\mathrm{PI}_{\mathrm{ABS}}$ is the photosynthetic performance indices from excitation to reduction of intersystem electron acceptors; RC/ABS is the number of active reaction centers (RC's) per energy absorbed; TR $/ \mathrm{ABS}\left(=\mathrm{F}_{\mathrm{v}} / \mathrm{F}_{\mathrm{y}}\right)$ is the quantum yield of photochemical reactions during absorption until reduction of primary electron acceptor of photosystem II- PSII $\left(\mathrm{Q}_{-}-\right)$; ET $/ \mathrm{ABS}\left(=1-\mathrm{F}_{1} / \mathrm{F}_{\mathrm{M}}\right)$ is the quantum yield in electron transport from $\mathrm{Q}_{-}$- to pool of plastoquinone $(\mathrm{PQ}) ; \mathrm{RE} / \mathrm{ABS}\left(=1-\mathrm{F}_{\mathrm{I}} / \mathrm{F}_{\mathrm{M}}\right)$ is the quantum yield in the reduction of final acceptors of photosystem I FSI; ET /TR is the efficiency of electron movement through electron transport chain transporters from $\mathrm{Q}$ - to plastoquinone $(\mathrm{PQ}) ; \mathrm{RE}_{0} / \mathrm{ET}_{0}$ is the efficiency with which an electron cam move from the reduced; $\mathrm{RE}_{\mathrm{T}} / \mathrm{TR}_{\mathrm{f}}$ is the efficiency with which a trapped exciton can move an electron into the electron transport chain from $\mathrm{Q}_{\mathrm{A}}-$ to the PSI end electron acceptors; and $\mathrm{PI}_{\mathrm{TQTAL}}$ is the photosynthetic performance indices from excitation to reduction of intersystem electron acceptors and from excitation to reduction of PSI final acceptors. Asterisks $\left(^{*}\right)$ indicate statistical differences between treatments by analysis of variance (ANOVA) at $5 \%$ probability $(\mathrm{n}=10)$.

Figura 1 - Fluorescência da clorofila a de plantas do ecotipo médio de Paubrasilia echinata Lam Gagnon,H.C.Lima e G.P.Lewis sob irradiância contrastante. (A) Cinética da fluorescência da clorofila a (curva OJIP) e (B) parâmetros matemáticos deduzidos da curva OJIP de folhas do morfotipo médio de $\boldsymbol{P}$. echinata Lam. cultivado em pleno sol $(\mathrm{O})$ e sombreamento natural $(\Delta)$. $\mathrm{DI} / \mathrm{RC}$ é o fluxo específico da dissipacão de energia no nível das clorofilas da antena; PIABS é o índice de desempenho fotossintético a partir da excitação até a redução dos aceptores de elétrons do intersistema; RC/ABS é a quantidade de centros de reação ativos ( $R C^{\prime}$ s) por energia absorvida; $\mathrm{TR}_{0} / \mathrm{ABS}\left(=\mathrm{F}_{\mathrm{V}} / \mathrm{F}_{\mathrm{M}}\right)$ é o rendimento quântico de reações fotoquímicas na absorção até a redução do receptor primário de elétrons do fotossistema II-FSII (QA-); ET /ABS (=1-FJ/FM) é o rendimento quântico no transporte de elétrons de $\mathrm{Q}$ - até o "pool'de plastoquinona $(\mathrm{PQ})$; $\mathrm{RE} / \mathrm{ABS}\left(=1-\mathrm{F}_{\mathrm{f}} / \mathrm{F}_{\mathrm{H}}\right)$ é o rendimento quântico na reducão dos aceptores finais do fotossistema I-FSI; $\mathrm{ET}_{0} / \mathrm{TR}_{0}$ é a eficiência dos movimentos dos elêtrons através dos transportadores da cadeia de transportes dos elétrons de $\mathrm{Q}_{\mathrm{A}}$ - para $\mathrm{PQ} ; \mathrm{RE}_{0} / \mathrm{ET}_{0}$ é eficiência dos movimentos dos elétrons da plastoquinona (PQ) para receptores finais de FSI; RE /TR é a eficiência com a qual um elétron pode se mover reduzido e PI é o índice de desempenho fotossintético da excitação até a redução dos receptores de elétrons do intersistema e da excitação até a redução dos receptores finais do FSI. Asteriscos $\left(^{*}\right)$ indicam diferenças estatísticas entre os tratamentos pela análise de variância (ANOVA) a 5\% de probabilidade (n $=10$ ).

The total performance index $\left(\mathrm{PI}_{\text {TОTAL }}\right)$ (a parameter that shows the total performance of photochemical reactions from light capture in the collecting complexes, transport of electrons between photosystems, to the final reduction in photosystem I) was kept in higher levels among directly sunlit plants (Figure 1B).

\subsection{Gaseous exchanges}

Besides the superiority in the photochemical phase of photosynthesis, the biochemical phase was no different: the plants under direct sunlight showed a higher capacity of carbon assimilation $(A)$ (Figure 2A), stomatal

conductance $\left(g_{s}\right)$ (Figure 2D) and transpiration $(E)$ (Figure 2C). These higher values in gaseous exchanges were positively reflected by water-use efficiency (WUE) (Figure 2E) and apparent carboxylation efficiency $\left(\mathrm{P}_{\mathrm{n}} / \mathrm{C}_{\mathrm{i}}\right.$ ) (Figure $2 \mathrm{G}$ ) compared to those in the shade. Intrinsic water-use efficiency (iWUE) was higher in sunlight (Figure 2F). The substomatal internal carbon concentration $\left(C_{i}\right)$ was higher among plants exposed to natural shading (Figure $2 \mathrm{~B}$ ), which confirms the higher assimilation of this gas $(A)$ in plants exposed to direct sunlight and, consequently, its reduction inside the mesophyll (Figure 2G). 


\subsection{Soluble carbohydrates}

The plants exposed to direct sunlight showed higher leaf concentrations of total soluble sugar, fructose, and glucose, but there was no difference in sucrose between treatments (Table 1). Carbohydrate concentration followed a decreasing proportion: total soluble sugar $>$ sucrose $>$ fructose $>$ glucose for both levels of irradiance. For the direct-sunlight treatment, glucose was the sugar that stood out most significantly, with values twice as high compared to the shaded plants (Table 1).

\subsection{Antioxidants}

The plants in natural shade had a total antioxidant capacity (ABTS) 1.6 higher than those exposed to direct sunlight (Figure 3D), as well as higher phenol contents (Figure 3B) in the same proportion. For enzymatic antioxidants, low irradiance resulted in more guaiacol peroxidase (POD) activity 1.6 higher in relation to full sunlight (Figure 3C). Superoxide dismutase (SOD) activity showed a more pronounced difference between the contrasting irradiances (Figure $3 \mathrm{~A})$. The SOD activity in natural shade was 3.8 higher than in sunlight.

\section{DISCUSSION}

The significant morphology of $P$. echinata plants under direct sunlight combined with thickening of their leaves, cuticle, mesophyll cell elongation and higher stomatal density, which are typical of pioneer species (Sabbi et al., 2010), confirm the heliophilous habit of this medium ecotype. These morphological adjustments increase resistance to water loss and control leaf temperature under high irradiance (Rossatto and Kolb, 2010).

Although palisade parenchyma elongation under direct sunlight was $70 \%$ higher than that of shaded plants, this strategy did not prevent oxidation of chloroplast pigments. However, this damage did not affect the carbon fixation reaction of plants under direct sunlight, where $A, g s$, and $E$ were higher than those among the shaded group. Consequently, WUE and $\mathrm{Pn} / \mathrm{Ci}$ were higher under direct sunlight, which supports the idea that heliophilous species have higher water use efficiency than ombrophilous species when exposed to high irradiance (Silva et al., 2010; Yang et al., 2018). Higher water-use efficiency under direct sunlight can be attributed to high stomatal density and adapted anatomical structure, which facilitates atmospheric $\mathrm{CO}_{2}$ spread to substomatal cavities and stimulate carboxylation reaction (Fini et al., 2010; Portela et al., 2019).

Higher concentrations of chlorophylls and carotenoids among the medium ecotype population in natural shading can be interpreted as an attempt to optimize photon absorption, regardless of wavelength, because the Chl. $a / b$ ratio did not vary between the two lighting conditions. Overall, ombrophilous species have low Chl. $a / b$ ratio in shaded areas (Lichtenthaler et al., 2007; Gaburro et al., 2017; Portela et al., 2019) because Chl. $b$ is specialized in capturing irradiance in wavelengths shorter than those of Chl. a (Lima et al., 2010). Anyhow, investment in the system of antennas in the shaded population did not increase carbon fixation, probably due to weak sunlight intensity or damage in the photochemical phase by oxygen reactive species.

This damaging reaction takes place in the oxidation complex of the water molecule during the photochemical phase, forming oxygen reactive species (ROS) incapable of being oxidized under intense shading (Sielewiesiuk, 2002; Gaburro et al., 2015). One of the ROS reactions consists in oxidizing the active reaction centers of PSII, and drastically affecting photochemical efficiency (Favaretto et al., 2011), which is shown by higher Chl. $a$ fluorescence among medium ecotypes in natural shading. Under high shading, the electron transport chain is affected, which compromises the synthesis of energetic compounds during the photochemical phase of photosynthesis (Sielewiesiuk, 2002). This is reflected by the low capacity to assimilate carbon (Baker, 2008; Mengarda et al., 2012; Zani et al., 2017; Portela et al., 2019), as seen among the medium ecotype population under natural shading.

The low photosynthetic capacity of medium ecotype under natural shading can also be confirmed by the lower concentrations of photo-assimilated (glucose, fructose, and sucrose) compared to the population under direct sunlight. Besides working as energy sources, these soluble carbohydrates can also sequester ROS (Terashima et al., 2006; Gaburro et al., 2015; Zani et al., 2017; Portela et al., 2019). For the small ecotype (semi-heliophilous), sensitive to high irradiance, tolerance to direct sunlight was overcome by increasing the concentrations of glucose, fructose, sucrose, and raffinose during the signalization phase and recovery of light stress (Mengarda et al., 2012). These carbohydrates also work as osmoregulators, attracting water molecules

Revista Árvore 2019;43(4):e430407 

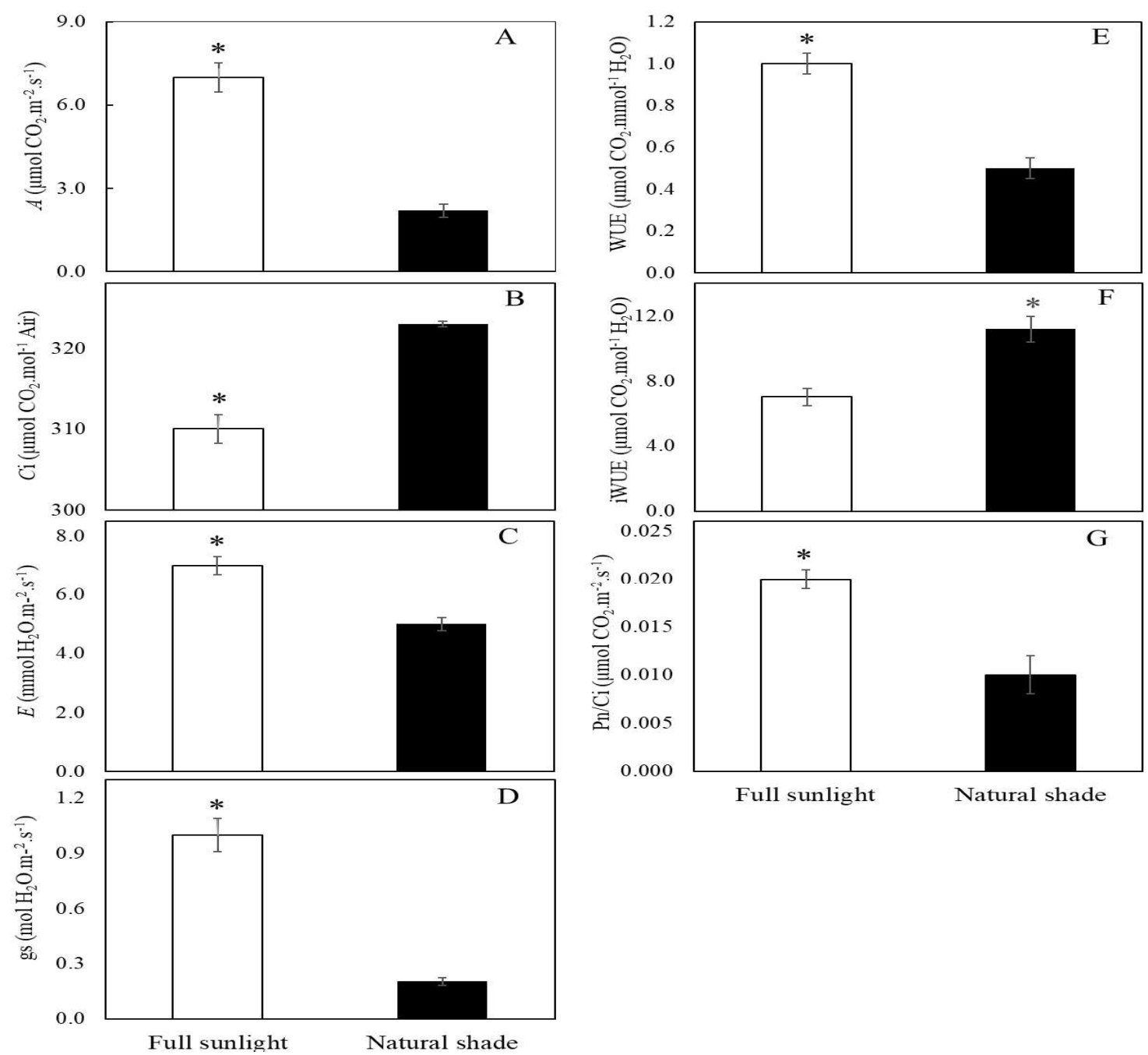

Figure 2 - Gaseous exchanges of medium ecotype plants of Paubrasilia echinata Lam Gagnon,H.C.Lima and G.P.Lewis. under contrasting irradiance. $\mathrm{A}$ is net $\mathrm{CO}_{2}$ assimilation, $(\mathrm{A}), \mathrm{C}$ is $\mathrm{CO}$ concentration in the intercellular airspaces $(\mathrm{B}), \mathrm{E}$ is transpiration rate (C), gs is stomatal conductance to water vapor (D), WUE is water-use efficiency (E), iWUE is intrinsic water use efficiency $(\mathrm{F})$ and $\mathrm{Pn} / \mathrm{C}_{\mathrm{i}}$ is apparent carboxylation efficiency $(\mathrm{G})$ of the medium ecotype of Paubrasilia echinata Lam. grown in full sunlight $(\mathrm{o})$ and natural shade $(\mathrm{n})$. Asterisks $(*)$ indicate statistical differences between treatments by analysis of variance $(\mathrm{ANOVA})$ at $5 \%$ probability $(\mathrm{n}=20)$.

Figura 2 - Trocas gasosas de plantas do ecotipo médio de Paubrasilia echinata Lam Gagnon,H.C.Lima e G.P.Lewis. sob irradiância contrastante. A é a assimilação liquid do CO2 (A), C é a concentração do CO2 nos espaços de ar intercelular (B), E é a taxa de transpiração (C), $g_{s}$ é a condutância estomática do vapor de água (D), WUE é a eficiência do uso da água $(E), i W U E$ é a eficiência intrinseca do uso da água $(F)$ e $P / C$ é a eficiência aparente da carboxilação $(G)$ do morfotipo médio de Paubrasilia echinata Lam. cultivado em pleno sol (o) e sombreamento natural (n). Asteriscos (*) indicam diferenças estatísticas entre os tratamentos pela análise de variância (ANOVA) a $5 \%$ de probabilidade $(n=20)$.

from the extracellular media into the vacuole (Kakani et al., 2011; Mengarda et al., 2012; Portela et al., 2019), which causes significant elongation of the palisade parenchyma in new leaves of the $P$. echinata small ecotype after exposure to direct sunlight (Mengarda et al., 2012). This osmoregulation action was also seen in the medium ecotype of the present study, in which leaves exposed to direct sunlight show $100 \%$ water content, higher than that of plants grown in shaded areas. This information confirms the role of non-structural carbohydrates as a promising criterion for successional classification (Li et al., 2016). 

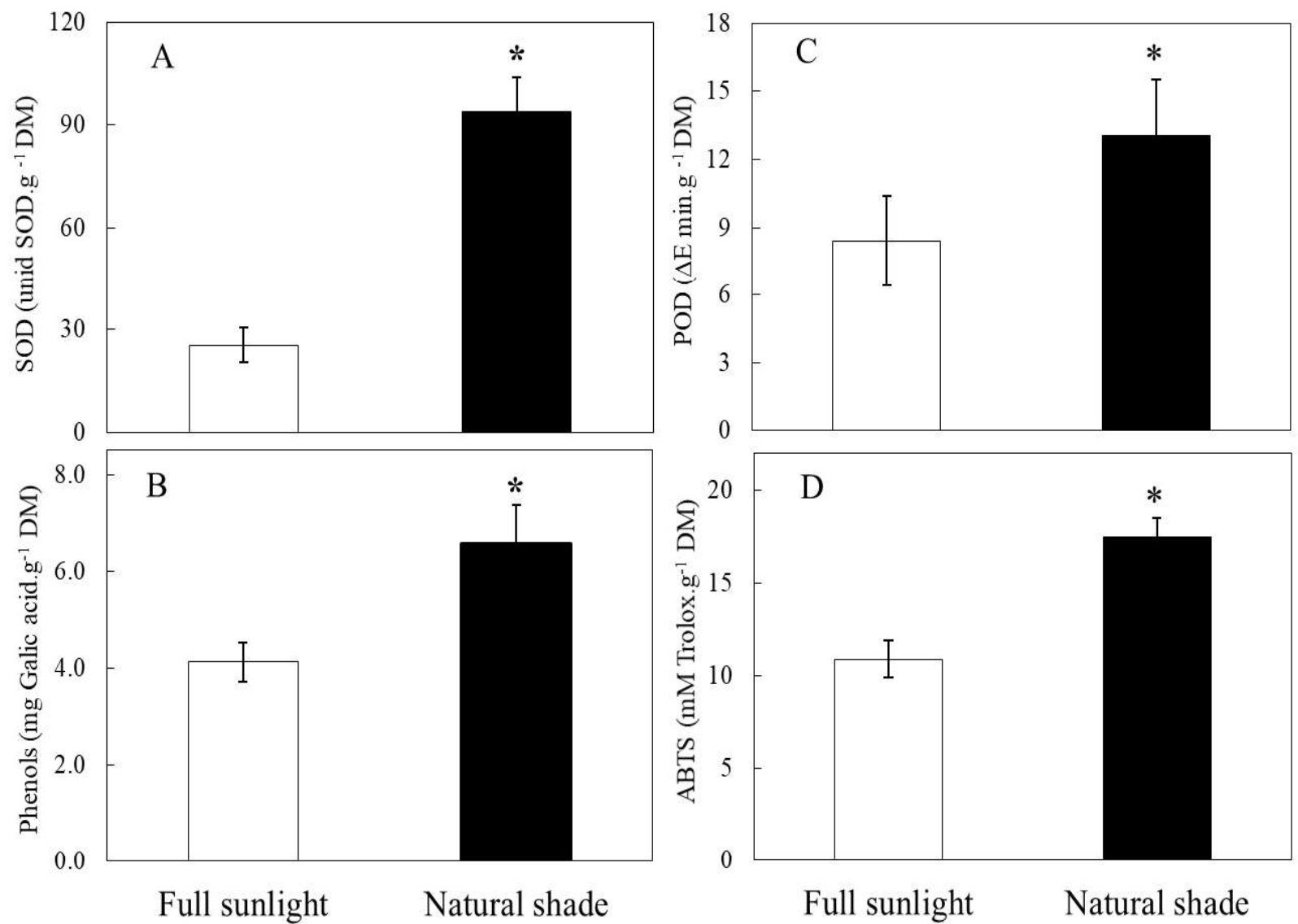

Figure 3 - Antioxidant activity of medium ecotype plants of Paubrasilia echinata Lam Gagnon,H.C.Lima and G.P.Lewis. under contrasting irradiance. Mean values of superoxide dismutase (SOD) activity (A), total phenols (B), guaiacol peroxidase (POD) activity (C) and total antioxidant capacity (ABTS) (D) of leaves of the medium ecotype of Paubrasilia echinata Lam. grown in full sunlight $(\mathrm{o})$ and natural shade $(\mathrm{n})$. Asterisks $(*)$ indicate statistical differences between treatments by analysis of variance (ANOVA) at $5 \%$ probability $(\mathrm{n}=6)$.

Figura 3 - Atividade antioxidante de plantas do ecotipo médio de Paubrasilia echinata Lam Gagnon,H.C.Lima e G.P.Lewis. sob irradiância contrastante. Valores médios da atividade de superóxido dismutase (SOD) (A), fenóis totais (B), atividade de peroxidase de guaiacol (POD), (C) e capacidade antioxidante total (ABTS) (D) de folhas do morfotipo médio de Paubrasilia echinata Lam. cultivado em pleno sol (o) e sombreamento natural (n). Asteriscos (*) indicam diferenças estatísticas entre os tratamentos pela análise de variância (ANOVA a $5 \%$ de probabilidade $(n=6)$.

The heliophilous habit of medium ecotype can also be confirmed by the increased antioxidant enzyme POD and SOD activity under natural shading, which is typical of pioneer trees in rain forests when exposed to $10 \%$ irradiance (Favaretto et al., 2011; Gaburro et al., 2015). In addition to their involvement in free radical neutralization, antioxidant enzymes also have an antagonistic effect in auxin activity. POD enzyme catalyzes the oxidation of this class of phytohormones recognized as a powerful regulator of growth and cellular expansion (Sofo et al., 2004). This can also explain the inhibited growth of medium ecotype of Brazilwood under natural shading.
Although the plants have shown higher POD and SOD activities in these conditions, the enzymatic mechanism was not enough to neutralize the ROS that destabilized the photochemical phase, which resulted in higher fluorescence rates and lower carbon fixation capacity. Consequently, instead of being used in carbon fixation, the reducing compounds may have deviated to the secondary metabolism, which is more active under high shading levels (Favaretto et al., 2011; Gaburro et al., 2017). This includes the synthesis of phenolic compounds, which are in higher concentrations in the medium ecotype under natural shading. Phenols and flavonoids work synergistically

Revista Árvore 2019;43(4):e430407 
with antioxidant compounds, getting accumulated in leaf tissues so as to increase resistance against adverse environmental conditions (Sankari et al., 2017) such as low irradiance.

The results in this study show that the heliophilous habit of medium ecotype of $P$. echinata owes much more to its efficient antioxidant metabolism since elongation of mesophyll cells did not prevent oxidation of chloroplast pigments under direct sunlight. Therefore, enzymatic (POD and SOD) and non-enzymatic (phenols and ABTS) antioxidant mechanisms of medium ecotype have shown to be very efficient under direct sunlight. Both photochemical and carboxylation phases worked effectively, with no signs of photodamage, which reflects the significant growth under direct sunlight. On the other hand, even with increased POD and SOD activity under natural shading, the enzymatic mechanism was not enough to stop the oxidative damage shown by higher Chl. $a$ fluorescence and lower photosynthesis.

\section{CONCLUSION}

We conclude that the medium ecotype of $P$. echinata has a sun-tolerant or pioneer species profile, as and such it is recommended that it be planted under full sunlight. The contradictions regarding ecological habits of $P$. echinata may be related to morphological and phylogenetic differences in the three ecotypes of this species. The physiological and biochemical characterization of these three morphological variations according to irradiance and other environmental factors are extremely important for attempts of new ecological structuring of $P$. echinata in its possible subspecific taxa. This information is essential for handling this species in Atlantic Forest recovery programs.

\section{ACKNOWLEDGMENTS}

The authors are thankful to the National Plan for Botany Support and Development - Coordination for the Improvement of Higher Education Personnel (PNADB-CAPES) for funding (grant 1147/2010) and granting a master's scholarship to the first author; to Reserva Natural Vale for supplying biological material and providing a study area. The last author thanks CNPq (Brazilian National Council for Scientific and Technological Development) for granting a productivity scientific scholarship (Process 305447/2012-2).

\section{REFERENCES}

Arnon DI. Copper enzymes in isolated chloroplast: polyphenoloxidase in Beta vulgaris. Plant Physiology. 1949;24(1):1-15. doi: 10.1104/pp.24.1.1

Baker NR. Chlorophyll fluorescence: a probe of photosynthesis in vivo. Annual Review of Plant Biology. 2008;59:89-113. doi: 10.1146/annurev. arplant.59.032607.092759

Brazilian National Institute of Meteorology INMET. Boletim agroclimatológico mensal. 2012. [accessed: 25 July 2015]. Available online: http:// www.inmet.gov.br. 2012

Budowski G. Distribution of tropical rain forest species in the light of successional progress. Turrialba. 1965;15(1):40-42.

Bukatsch F. Bemerkungen zur doppelfärbung astrablau-safranin. Mikrokosmos. 1972;61:255.

Bulbovas P, Rinaldi MCS, Delitti WBC, Domingos M. Variação sazonal em antioxidantes em folhas de plantas jovens de Caesalpinia echinata Lam. (pau-brasil). Revista Brasileira de Botânica. 2005;28(4):687-696. doi: 10.1590/S010084042005000400004

Dubois M, Gilles KA, Hamilton JK, Rebers PA, Smith F. Colorimetric method for determination of sugars, and related substances. Analytical Chemistry. 1956;28(3):350-356. doi: 10.1021/Ac60111a017

Favaretto VF, Martinez CA, Soriani HH, Furriel RPM. Differential responses of antioxidant enzymes in pioneer and late-successional tropical tree species grown under sun and shade conditions. Environmental and Experimental Botany. 2011;70(1):20-28. doi: 10.1016/j. envexpbot.2010.06.003

Fini A, Ferrini F, Frangi P, Amoroso G, Giordano C. Growth, leaf gas exchange and leaf anatomy of three ornamental shrubs grown under different light intensities. European Journal of Horticultural Science. 2010;75(3):111-117.

Gagnon E, Bruneau A, Hughes CE, Queiroz LP, Lewis GP. A new generic system for the pantropical Caesalpinia group (Leguminosae). PhytoKeys. 2016;71:1-160. doi: 10.3897/phytokeys.71.9203 
Gama VN. Análises Morfofisiológicas de Plantas de Pau-Brail (Caesalpinia echinata Lam.) cultivadas em pleno sol e em sombreamento natural. [Dissertation]. Vitória (ES): Federal University of Espírito Santo; 2013.

Hiscox JD, Israelstam GF. A method for the extraction of chlorophyll from leaf tissue without maceration. Canadian Journal of Botany. 1979;57(12):1332-1334. doi: 10.1139/b79-163

Hossain MA, Rahman SMM. Total phenolics, flavonoids and antioxidant activity of tropical fruit pineapple. Food Research International. 2011;44(3):672-676. doi: 10.1016/j.

foodres.2010.11.036

Hunt R. Plant growth curves: the functional approach to plant growth analysis. London, UK: Edward Arnold Publishers; 1982. doi: 10.1017/ S0014479700022857

Jermyn MA. A new method for the determination of ketohexoses in presence of aldohexoses. Nature. 1956;177:38-39. doi: 10.1038/177038a0

Juchum FS, Costa MA, Amorim AM, Corrêa RX. Phylogenetic relationships among morphotypes of Caesalpinia echinata Lam. (Caesalpinioideae: Leguminosae) evidenced by trnL intron sequences. Naturwissenschaften. 2008;95(11):1085-1091. doi: 10.1007/s00114-008-0424-6

Anjum SA, Ashraf U, Tanveer M, Khan I, Hussain S, Shahzad B, et al. Drought induced changes in growth, osmolyte accumulation and antioxidant metabolism of three maize hybrids. Front Plant Sci. 2017;8:69. doi: 10.3389/fpls.2017.00069

Kakani VG, Vu JC, Allen Jr LH, Boote KJ. Leaf photosynthesis and carbohydrates of $\mathrm{CO} 2-$ enriched maize and grain sorghum exposed to a short period of soil water deficit during vegetative development. Journal of Plant Physiology. 2011;168(18):21692176. doi: 10.1016/j.jplph.2011.07.003

Klumpp G, Guderian R, Küppers K. Peroxidase und Superoxiddismutase- Aktivität sowie Prolingehalte von Fichtennadeln nach Belastung mit O3, SO2 und NO2. European Journal of Forest Pathology. 1989;19(2):84-97. doi: 10.1111/j.1439-0329.1989. tb00238.x
Lako J, Trenerry VC, Wahlqvist M, Wattanapenpaiboon N, Sotheeswaran S, Premier R. Phytochemical flavonols, carotenoids and the antioxidant properties of a wide selection of Fijian fruit, vegetables and other readily available foods. Food Chemistry. 2007;101(4):1727-1741. doi: 10.1016/j.foodchem.2006.01.031

Li N, He N, Yu G, Wang Q, Sun J. Leaf nonstructural carbohydrates regulated by plant functional groups and climate: evidences from a tropical to cold-temperate forest transect. Ecological Indicators. 2016;62:22-31. doi:10.1016/j.ecolind.2015.11.017

Lichtenthaler HK. Chlorophylls and carotenoids: pigments of photosynthetic biomembranes. In: Packer L, Douce R (Eds.) Methods in Enzimology. London: Academic Press. 1987;148:350-381. doi: 10.1016/0076-6879(87)48036-1

Lichtenthaler HK, Ač A, Marek, MV, Kalina J, Urban O. Differences in pigment composition, photosynthetic rates and chlorophyll fluorescence images of sun and shade leaves of four tree species. Plant Physiology and Biochemistry. 2007;45(8):577588. doi: 10.1016/j.plaphy.2007.04.006

Lima MAO, Mielke MS, Lavinsky AO, França S, Almeida AAF, Gomes FP. Crescimento e plasticidade fenotípica de três espécies arbóreas com uso potencial em sistemas agroflorestais. Scientia Forestalis. 2010;38(87):527-534.

Lima HC. Aspectos botânicos do pau-brasil. In: Cunha MW, Lima HC (Eds.). Viagem à terra do paubrasil. Rio de Janeiro: Agência Brasileira de Cultura; 1992. p. 23-38.

Lorenzi H. Árvores brasileiras. 4rd ed. Nova Odessa, SP: Plantarum; 2002. v. 1.

Mengarda LHG, Milanez CRD, Silva DM, Aguilar MAG, Cuzzuol GRF. Morphological and physiological adjustments of brazilwood (Caesalpinia echinata Lam.) to direct solar radiation. Brazilian Journal of Plant Physiology. 2012;24(3):161-172. doi: $10.1590 / \mathrm{S} 1677-04202012000300003$

Mengarda LHG, Souza RLF, Campostrini E, Reis FO, Vendrame WA, Cuzzuol GRF. Light as an indicator of ecological succession in brazilwood (Caesalpinia echinata Lam.). Brazilian Journal of Plant Physiology. 2009;21(1):55-64. doi: 10.1590/ S1677-04202009000100007 
Parida AK, Das AB, Mittra B. Effects of salt on growth, ion accumulation, photosynthesis and leaf anatomy of the mangrove, Bruguiera parviflora. Trees. 2004;18(2):167-174. doi: 10.1007/s00468-003-0293-8

Portela FCS, Macieira BPB, Zanetti LV, Gama VN, Silva DM, Milanez CRD, et al. How does Cariniana estrellensis respond to different radiance levels?. Journal of Forestry Research. 2019;30(1):31-44. doi:10.1007/s11676-017-0578-1

Riazi A, Matsuda K, Arslan A. Water-stress induced changes in concentrations of proline and other solutes in growing regions of young barley leaves. Journal of Experimental Botany. 1985;36(11):1716-1725. doi: $10.1093 / \mathrm{jxb} / 36.11 .1716$

Rossatto DR, Kolb RM. Gochnatia polymorpha (Less.) Cabrera (Asteraceae) changes in leaf structure due to differences in light and edaphic conditions. Acta Botanica Brasilica. 2010;24(3):605-612. doi: $10.1590 / \mathrm{S} 0102-33062010000300002$

Sabbi LBC, Ângelo AC, Boeger, MR. Influência da luminosidade nos aspectos morfoanatômicos e fisiológicos de folhas de Schinus terebinthifolius Raddi (Anacardiaceae) implantadas em duas áreas com diferentes graus de sucessão, nas margens do Reservatório Iraí, Paraná, Brasil. Iheringia Série Botânica. 2010;65(2):171-181.

Sankari M, Hridya H, Sneha P, Doss CGP, Ramamoorthy S. Effect of UV radiance and its implications on carotenoid pathway in Bixa orellana L. Journal of Photochemistry and Photobiology B, Biology. 2017; 176:136-144. doi: 10.1016/j. jphotobiol.2017.10.002

Sielewiesiuk J. Why there are photodamages to photosystem II at low light intensities. Acta Physiologiae Plantarum. 2002;24(4):399-406. doi: $10.1007 / \mathrm{s} 11738-002-0036-2$
Silva AS, Oliveira JG, Cunha M, Vitória AP. Photosynthetic performance and anatomical adaptations in Byrsonima sericea DC. under contrasting light conditions in a remnant of the Atlantic Forest. Brazilian Journal of Plant Physiology. 2010;22(4):245-254. doi: 10.1590/ S1677-04202010000400004

Sofo A, Dichio B, Xiloyannis C, Masia A. Effects of different radiance levels on some antioxidant enzymes and on malondialdehyde content during rewatering in olive tree. Plant Science. 2004;166:293-302. doi: 10.1016/j.plantsci.2003.09.018

Strasser RJ, Tsimilli-Michael M, Srivastava A. Analysis of the fluorescence transient. In: Papageorgiou GC, Govindjee G (Eds.) Chlorophyll fluorescence: a signature of photosynthesis. Dordrecht: Springer; 2004. p.321-362. Advances in Photosynthesis and Respiration Series.

Terashima I, Hanba YT, Tazoe Y, Vyas P, Yano S. Radiance and phenotype: comparative ecodevelopment of sun and shade leaves in relation to photosynthetic $\mathrm{CO} 2$ diffusion. Journal of Experimental Botany. 2006;57(2):343-354. doi. org/10.1093/jxb/erj014

Yang F, Fan Y, Wu X, Cheng Y, Liu Q, Feng L, et al. Auxin-to-gibberellin ratio as a signal for light lntensity and quality in regulating soybean growth and matter partitioning. Frontiers in Plant Science. 2018;9(56):1-13. doi: 10.3389/fpls.2018.00056

Zani LB, Macieira BPB, Corte VB, Milanez CRD, Cuzzuol GRF. The vessel elements and hemicelluloses as the most plastic structural components of the brazilwood ontogeny (Caesalpinia echinata Lam.) medium morphotype. Brazilian Journal of Botany. 2017;40(3):793-800. doi: $10.1007 / \mathrm{s} 40415-017-0375-2$ 